PART 2

France 
Thomas Haye - 9789004378216

Downloaded from Brill.come4/26/2023 02:37:46PM via free access 


\title{
The Construction of a National Past in the Bella Britannica by Humbert of Montmoret (d. ca. 1525)
}

\author{
Thomas Haye
}

\section{Introduction}

In the early 16 th century, the European peoples experienced an extremely dynamic boost to their collective self-reassurance. One particularly important vehicle in this construction of a national consciousness was history as mediated by literature. Interestingly, each of the continent's nations evolved its own system of references, which might be more or less dominant. For example, while in Italy Roman antiquity developed into a central theme, in France it was the immediate past, i.e., the High Middle and Late Middle Ages, that played a markedly greater role. It was especially the dissociation from England during the Hundred Years' War that contributed materially to the formation of French self-consciousness. Antiquity, literally the "old time," here proved to be a serial plural, a succession of historical layers extending from the mythical past into the late $15^{\text {th }}$ century.

How the French "antiquities" were used as the modern era unfolds is exemplified in the historical-panegyric poetry of Humbert of Montmoret (Humbertus Monsmoretanus). Almost nothing is known about the author, ${ }^{1}$ except that he came from the Duchy of Burgundy, may have entered the Benedictine monastery near Vendôme toward the end of his life and died there around the year $15^{25}$. Surviving in print is a series of his poems in Latin, some of which treat religious themes while others deal with contemporary times and the more recent history of France. ${ }^{2}$ Thus, in the year 1513 , he

1 On the author, see Provini S., "Lécriture épique de Germain de Brie et d'Humbert de Montmoret et l'humanisme italien", in Deramaix M. et al. (ed.), L'Italie et la France dans l'Europe latine du XIV e au XVII e siècle (Mont-Saint-Aignan: 2006) 79-93, here 79-80; Provini S., L'Écriture épique au début de la Renaissance. Humbert de Montmoret, Germain de Brie, Pierre Choque, L'incendie de la Cordelière (La Rochelle: 2004) 17-18; Kouskoff G., "Deux Epopées néo-latines à la gloire d'Hervé, le Nauchier breton", in Chevallier R. (ed.), Colloque L'Épopée Gréco-Latine et ses Prolongements Européens. Calliope II (Paris: 1981) 199-216, here 200-201.

2 On the epic poems, see Braun L., Ancilla Calliopeae. Ein Repertorium der neulateinischen Epik Frankreichs (1500-1700), Mittellateinische Studien und Texte 38 (Leiden - Boston: 2007) 74-91.

(C) THOMAS HAYE, 2019 | DOI:10.1163/9789004378216_008

This is an open access chapter distributed under the terms of the prevailing CC-BY-NC-ND License at the time of publication. 
publishes a Herveis, followed by a Bellum Ravenne in 1513/14 and a collection of Duodecim Silvae in 1514; also in print is another, undated poem on the life of Christ (Christis). ${ }^{3}$

The most significant work in the oeuvre, however, are the Bella Britannica, an epic of some 3,000 verses divided into seven books which was published by Josse Bade in Paris in January $1513 .{ }^{4}$ Montmoret at this point may already have lived as a monk at Vendôme, since he addressed the poetic praefatio (as well as a subsequent series of distichic epigrams) to his abbot Louis de Cravant. ${ }^{5}$ In it, Montmoret describes the epic as his literary firstling composed in less than three months. ${ }^{6}$ It may be that he had entered the monastery not long before.

The text deals with the years 1422-1429, that is, only a short stretch of the Hundred Years' War. Since the title mentions a 'prima pars, ${ }^{7}$ the author may have planned a sequel covering the later years. ${ }^{8}$ But there is no trace of it having been realized. Occupying a special place in the narrative are the heroic deeds by the Maid of Orleans; also, King Charles VII of France (1422-1461) takes the stage as a second protagonist. However, this is not to say that the text is exclusively tailored to a single heroic figure. Although Montmoret's epic uses numerous motifs from Virgil's Aeneid, it is not primarily oriented toward individual persons (as the title Bella Britannica already indicates). It recounts instead the collective struggle of the French people against the English. A better conceptual comparison might be the Punica composed by Silius Italicus,

3 On the Christis, see Czapla R.G., Das Bibelepos in der Frühen Neuzeit. Zur deutschen Geschichte einer europäischen Gattung, Frühe Neuzeit 165 (Berlin - Boston: 2013) 522; IJsewijn J. (with D. Sacré), Companion to Neo-Latin Studies. Part II.Literary, Linguistic, Philological and Editorial Questions. Second, entirely rewritten edition, Supplementa Humanistica Lovaniensia 14 (Leuven: 1998) 29.

4 See Braun, Ancilla Calliopeae 81-88. In what follows, the quotes from the 1513 edition are not graphically modernized; solely the abbreviations (also the $e$ caudata) are resolved and the $u$ is differentiated from $v$. In this edition, punctuation is minimal. For enhanced understanding, the citations are punctuated according to the rules of German orthography. Upper and lower case are similarly adapted.

5 "Ad reverendum in Christo patrem dominum Ludovicum de Crevanto, abbatem Vindocimensem [!] carmen ex tempore", fol. A II r. In Book 3, the epic deals among others with the Bellum Cravantinum, i.e., the battle of Cravant (30 July 1423). The abbot thus may have harbored a local patriotic interest in the account.

6 Praefatio, vv. 16-18 (fol. A II r): '[...] nostri / Ingenii tibi primitias studioque trimestri / Sudatum prebemus opus [...]' - 'We hereby render unto you the firstling of our talent, a work we produced with our zealous sweat in three months'.

7 Title leaf: Fratris Humberti Montis Moretani poetae oratorisque clarissimi Bellorum Britannicorum a Carolo Francorum rege eo nomine septimo in Henricum Anglorum regem foelici euentu auspice puella franca gestorum prima pars continens [...].

8 See Braun, Ancilla Calliopeae 81-88. 
which also glorify a certain community by differentiating it from another, hostile collective.

Although Montmoret is regarded in modern literary historiography as a poet influenced by Italian humanism, the narrative style cultivated in this epic seems 'eher mediaeval.' ${ }^{9}$ This may be accounted for by the fact that most of the poem is based on a prose report from the Late Middle Ages written on royal commission by a monk named Jean Chartier, a contemporary and eye witness of the events depicted whose work was printed in 1476/1477 in the Grandes Chroniques de Saint Denis (and again in 1493). Since Montmoret treats not contemporary history but instead France's - more recent - past, he is forced to rely entirely on this written source.

There is also scarcely anything of the humanistic to be found in the literary technique. Certainly, the poem employs the genre-typical elements of the epic, but these cannot be assigned to a particular era: Having come into use in antiquity, most of them were also used in the Middle Ages, and in the Renaissance as well. Moreover, Montmoret follows the ordo naturalis, portraying the historical events, particularly military actions on both sides (battles and sieges), sequentially; in addition, he lets divine powers intervene and weaves in some fairly long speeches by and dreams of the protagonists for the sake of relief or characterization. Besides the historical figures, he has God the Father or Jupiter appear, also Mary and the sainted Dionysius; further, there is the sun god Phoebus and the Cyclopes, as well as the personifications Fama and Ratio and the Furies.

In the first book, the author addresses King Louis XII of France (1498-1515) and promises to sing of him later in panegyric verses (fol. I v):

Posterius tua facta canam, superataque forti

Regna manu nostris adiungent saecla libellis.

Et mea perpetuo describens pagina versu,

Strenua quae in Latiam gessisti praelia gentem,

Ibit in aeternos cedro vivacior annos. ${ }^{10}$

Montmoret here holds out the prospect of celebrating contemporary events in song, namely, the successes Louis met with in Italy (and especially against

$9 \quad$ Braun, Ancilla Calliopeae 81; see there also 88: 'Mediaeval-statische Beschreibungen'.

10 'Later will I sing of your deeds, and the kingdoms conquered with a strong hand will bestow on our books centuries [sc. of response]. And my page, which, with undying verse, describes what magnificent battles you fought against the Italian people, will stride longer-lived than a cedar into eternity'. 
Venice). Let the depiction at hand of the Hundred Years' War hence be nothing more than prelude: '[...] iam nunc praeludia quaedam / [...] / Incipiam [...]' (fol. I v). This is no empty promise: Already in 1513 (or 1514), the Bellum Ravenne appears in print celebrating the victory won by Louis over Pope Julius II and the Holy League. ${ }^{11}$

\section{2 The Presentations of the Past in Montmoret's Epic}

In Montmoret's text it is not just the French but also their English adversaries who can look back on a glorious past which impels them to fresh deeds. Thus, the poet describes in the second book how King Henry VI of England (14221461 and 1470-1472) and his noble counselors sit at table in a courtly hall that is decorated with marvellous tapestries depicting scenes from Britain's history. ${ }^{12}$ They see here first of all the legendary conquest and settlement by the Britons, Picts, and Danes. Then, in a different place, there is the legendary Brittonic King Lucius who is said to have converted his people to Christianity in the 2nd century. ${ }^{13}$ Another of the tapestry's scenes shows the Brittonic King Arthur vanquishing the Scots, Saxons, and Romans, aided by Merlin, the equally legendary sorcerer and prophet. ${ }^{14}$ Roman antiquity is not entirely eclipsed here, but what dominates is a depiction of a mythic, historic past that is not fixated

11 On the text, see Braun, Ancilla Calliopeae 89-91.

12 Fol. XIIII r: 'Atria barbaricis ornata tapetibus intrant / Egregii proceres lanisque insculpta tuentur / Magnorum facta alta patrum moresque vetustos / Actaque magnanimas cernunt stimulantia mentes: / Scilicet ut saevi traiectis Britones undis / Celsa Albioniis posuerunt moenia terris, / Qualiter et Picti Daunique in bella feroces / Struxerunt per rura domos [...]' - 'The splendid knights enter halls adorned with barbarian [i.e., dating from pre-Christian times] tapestries and regard the noble deeds - depicted in the wool - of the great forefather and the old customs, and they see actions that make their great hearts pound: say, how the wild Britons after crossing the waves erected steep walls in Albion; and how the warlike Picts and Danes built their houses on the fields'.

13 Fol. XIIII r: 'Parte alia auratis fulgebat Licius armis, / Sancta Panomphaei recolens qui iussa tonantis / Barbara frangebat vanorum altaria divum' - 'In another place, Licius [= Lucius] blazed with golden weapons, and, remembering the sacred orders of the thundering Panomphaeus [= God] he destroyed the barbaric altars of false deities'.

14 Fol. XIIII v: 'Fulminat hic Arcturus atrox Pictosque volucres / Persequitur pellitque suis Saxones ab oris, / Oenotrias sternitque acies ususque sagacis / Merlini auxilio, quo non praestantior alter / Augurio (huic dederat ventura elapsaque summus / Scire pater) bellis terret crudelibus orbem' - 'Here again shines the wild Arthur, and he pursues the fastmoving Picts, drives the Saxons from his shores, subdues the Oenotric [= Roman] hosts, and, helped by the clever Merlin (there was no better seer, for the Father on high [= God] had given him the gift of kenning the future and past), terrorizes the world with merciless wars'. 
on Rome but on the British isle and feeds entirely on sources from the Early Middle Ages.

In the epic, to an even greater degree, the thoughts and doings of the French protagonists are determined by a past in which the pagan Rome of antiquity is only one instance among many. Thus, the poet describes how the French king Charles addresses his troops. ${ }^{15}$ To fire up his compatriots' patriotism, the monarch reminds them of the purportedly numerous defeats that the French had inflicted on the English in the 14th and early 15th centuries. Going even further, the king evokes the memoria of the Migration Period when the Franks defeated the legions of the Roman Emperor Theodosius (379-395). ${ }^{16}$ With the English clearly less capable militarily than the formidable Romans, the French were able to beat them without difficulty. Montmoret now explains that the king's address stoked the French soldiers' desire to give battle significantly and then proceeds to a terse characterization of his compatriots. His choice of historical references here is instructive. Thus, he starts off with (fol. XXII v):

\author{
Gallus enim parvo magnas fert corpore vires. \\ $[\ldots]$ \\ Aut quales Orladus atrox, cui corpore parvo \\ Tanta fuit virtus, ut pauco milite cinctus \\ Impia prostrarit Marsilli castra superbi \\ Vicerit et magnum clava, non ense, gigantem. ${ }^{17}$
}

15 Fol. XXI r-v: 'Nunc opus est obstare animo patriamque focosque, / Uxores, natos, altaria sacra, penates / Nostraque districto defendere corpora ferro. / Post tantos patrum terraque marique triumphos / Turpe foret perferre iugum gentisque superbae / Elatas tolerare manus, quas Gallia saepe / Victrici fudit mediis certamine campis' - 'Now it is necessary to resist courageously and to defend homeland, hearth, wives, children, sacred altars, dwellings and our bodies with drawn sword. After such victories by our ancestors on water and on land, it would be shameful to be yoked and have to abide the hand raised in triumph [or: the boastful troops] of a proud people that Gaul often in victorious battle swept from the midst of the battlefield'.

16 Fol. XXI v: 'Si quondam Oenotrias virtus Franconia gentes / Thedosiique acies campo expulit [...], / [...] / Cur nunc longe animis Anglos et viribus infra / Non potero assumptis propellere fortiter armis?' - 'If at one time Frankish courage drove the Oenotric [= Roman] people and the legions of Theodosius from the field [...], why would I not pick up weapons now and forcefully drive off the English who, in courage and strength of arms, rank far below the Romans?'.

17 'The Gaul may have been of small stature, but he possesses great strengths [...] Or, as for example the terrible Roland, who, although he was of slight build still had such great courage that, aided by only a few soldiers, defeated the godless forces of the proud Marsilius, vanquishing the powerful giant with a mere club and not a sword'. 
Montmoret here points to the Frankish knight Roland who, legend has it, fought the Saracen prince Marsilus (or Marsilius) with great bravery during Charlemagne's invasion of Spain. This is followed by another historical remembrance (fol. XXII v):

Fortia quid referam magni certamina regis?

Cui deus astrifero fluentia misit Olympo

Lilia $[\ldots] .^{18}$

Here Montmoret evokes the Merovingian King Clovis (481-511) who, after beating the Alemanni (i.e., after the battle of Zülpich in the year 496), is said to have converted to Roman Christianity. According to late medieval legend, Clovis was the first to display the lilies sent by God on the Frankish coat of arms. And Charles continues his address thus (fol. XXII v):

Quid Magnum Magnique patrem fortemque Philippum

Romula Francigenis miscentem pila catheiis? ${ }^{19}$

Montmoret here points first to Charlemagne's Italian campaign and the victory he scored over the Lombard King Desiderius in the year 774. Second, he refers to Charlemagne's father Piepin the Younger $\left(75^{-768)}\right.$ and his Italian campaigns in 755 and 756 . Third, the poet invokes the French King Philipp II Augustus (1180-1223), who, although he did spend time in Italy on returning from the Holy Land, did not wage war there. Montmoret mentions him here because of his great political and military successes. Finally, the king's speech evokes one more ruler:

Quid repetam, quanto Lodoicus turbine movit In Machometiacos horrentia praelia Turcas?20

Meant here is the French King Louis VII (1137-1180) who took part in the Second Crusade to the Holy Land.

18 'Why should I recall the great king's battles? God let the lilies float down to him from starred Olympus'.

19 'Why should I recall the Great One and his father, the brave Philip? They all let Roman javelins hit Frankish cudgels'.

20 'Why should I remind of the mighty turmoil of Louis waging merciless wars against the Mohammedan Turks?'. 
Summing up: The author by a series of short vignettes here recalls for the reader a long history of the Franks and, respectively, the French that stretches from Late Antiquity to the 13th century. This allegedly glorious past does not derive from pagan Roman antiquity, rather it is at best comparable to it.

In the fourth book, Montmoret describes how Saint Dionysius seeks out the sun god Phoebus and implores him while a battle is raging between the English and French to blind the opposing forces with his blaze. He justifies his entreaty by stating that no other nation is as close to his heart as the French. ${ }^{21}$ For no other nation is as closely tied to the Christian faith, no other fights the enemies of the Christian God like it does. Here the poet once more alludes to important instances, events, and persons of Frankish and, respectively, French history: The reference here may be to the Merovingian kings adopting the Christian faith and confessing to the Roman church, also the victories won by Charles Martell (d. 741) over the Saracens, as well as Charlemagne proselytizing the Saxons. Indirectly, the military engagement by the French crusaders is also recalled.

In the last half of the seventh book, i.e., toward the epic's end and therefore at a prominent place in the text, the poet describes a tapestry being hung in Joan of Arc's tent. The long section is the counterpart of the aforementioned passage in the second book in which the banqueting English marvel at tapestries illustrating the history of Britain. The tapestry now on display in Joan of Arc's tent shows scenes of the Trojan War and of the Frankish mythology that derived from it. ${ }^{22}$ Meeting the eye first is Hector's attack on the Greek ships, ${ }^{23}$ a next scene shows the Trojan Francio, mythical progenitor of the Frankish and respectively of the French people, fleeing to Gaul where he trains their

Fol. xxxv v: 'Nulla mihi certe picti sub cardine caeli / Gratior esse potest quam Galli bella potentis / Natio. Sacratis nulla est quae saepius aris / Thura ferat. Nulla est, cui post documenta remansit / Clavigeri magis ampla fides; nulla insuper, ipsos / Quae totiens fidei rabidos perterruit hostes' - 'Certainly, no nation under the colorful heavens turning above can be more welcome to me than the splendid nation of the mighty Gaul. No nation sacrifices more often at the sacred altars. There is no nation, so it is handed down to us, that has demonstrated greater enduring loyalty to the key bearer [= the Pope]. Furthermore, no other nation has driven the wild enemies of our faith away more often'.

22 See the table of contents in Braun, Ancilla Calliopeae 87.

23 Fol. LVII v: 'Castra coloratis variata tapetibus, in quis / Acta legebantur magnorum illustria regum. / Illis magnanimum crudelibus Hectora in armis / Cernere erat Danaas cupientem accendere puppes' - '[They set up] a camp that was colorfully decorated with colored tapestries. On them they could follow the famous deeds of the great kings. On others they saw how the magnanimous Hector bearing cruel weapons wanted to set the Danaic [= Greek] ships on fire'. 
forefathers in how to win at war. ${ }^{24}$ The French nobles present in the tent gaze spellbound at the scenes depicted on the tapestry. ${ }^{25}$ For the observer, mythical history serves to stimulate his own performance. After they have supped and night has fallen, the nobles sit together to tell stories and reminisce about the glorious events of that day. The visual memoria now segues into an oral-auditory one. Spoken of now are the military feats that Joan of Arc accomplished as well as the mythic Franks descended from Priam or other Trojans. ${ }^{26}$ Next, a minstrel by the name of Ioppas appears ${ }^{27}$ and performs a few songs that also point first to the Franks' Trojan heritage. ${ }^{28}$ So, the citharist has the Franks, after vanquishing the Alemanni, also repulse the legions of the Roman emperor Theodosius (370-395). ${ }^{29}$ In keeping with the medieval narrative tradition, myth here blends seamlessly into history. Frankish history may be loosely integrated with the history of the ancient Romans and related to it, but, more importantly, it first achieves its own renown by differentiation from the Romans.

Ioppas then continues to sing of the first Merovingian king Pharamond who, legend has it, reigned in the 5 th century. ${ }^{30}$ Next come allusions to Merovech,

24 Fol. LVII v-LVIII r: '[...] saevisque elapsus Achivis / Francio discedens Gallas veniebat ad oras, / Quas post ipse suo Francas de nomine dixit. / Hic docuit Gallos ferre arma $[\ldots] /[\ldots]$ / Inclyta sic Francae surrexit gloria gentis' - 'Francio, having escaped the wild Achaeans [= Greeks], reached the Gallic shores which he later called Frankish after his own name. He taught the Gauls how to fight war [...] In this way the oft-cited fame of the Frankish people came to be'.

25 Fol. LVIII r: 'Dum passim heroes per castra ornata refusi / Picturam aspicerent, picturam corda moventem / Pascentemque animos imitandaque in acta trahentem, / Exornant famuli mensas [...]' - 'While the heroes scattered around the decorated encampment regarded the picture that moves their hearts and feeds their courage and spurs them on to exemplary deeds, the servants set the tables [...]'.

26 Fol. LVIII r: 'Vocibus alternis nunc strenua facta parentum / Enarrant proceres, validae nunc quanta puellae / Corpora fulmineo prostrarit lancea cursu. / Priamidas alii genitosque a sanguine Francos / Dardanidum [...]' - 'The knights took turns telling now of the ancestors' brave deeds, now of how the strong girl's [= Joan of Arc] spear like lightning threw the bodies [sc. of the enemy] to the ground. Other talked about Priam's descendants and the Franks descended from the blood of the Dardanians [= Trojans]'.

27 See Virgil, Aeneis I, 740.

28 Fol. LVIII r: 'Concinit Hectoridas patria a statione repulsos, / Qui Gallas coluere plagas, et Francia tandem / Fortis in immensum victis ut crevit Halanis' - 'He sings of Hector's offspring driven from their homes to then settle the Gallic lands, and how the brave Franconia grew immeasurably after the victory over the Alani [meaning the Alemanni]'

29 Fol. LVIII v: 'Thedosiique acies violento Marte reiecit' - '[The Frankish people] repelled in violent war the troops of Theodosius'.

30 Fol. LVIII v: 'Hic quoque clara canit Pharamundi gesta diserto / Carmine [...]' - 'In his dulcet song, he also extols the renowned deeds of Pharamond'. 
according to legend the progenitor of the Merovingians, who also ruled in those days, and to his son Childeric I (d. 481/482) (fol. LVIII v):

Laudat et insignem clara virtute Moroveum
Surgentemque illa prolem radice superbum
Childericum, fudit rigido qui Marte potentes
Romulidas vicitque ferum sua regna tenentem
Gillonem et validis Odoagrum reppulit armis. ${ }^{31}$

Montmoret here also shows how the history of the Franks successively emancipated itself from the history of the Romans: Childeric is victorious over the Roman usurper Aegidius (called Gillo here) and the Germanic warlord Odoacer, who was also in Roman service.

After Ioppas has finished his song, an older soldier holds a laudation on the martial prowess of the French, which begins with the following words (fol. LVIII v):

\section{Francia, magnorum nutrix animosa virorum, In magnas laxata acies victricibus armis Eoos calcavit agros quaesitaque bello regna triumphatis tenuit Nabathaea tyrannis. ${ }^{32}$}

With this, the poet again, and now explicitly, refers to the Crusades of the 11th and 12th centuries in which the kings and knights of France played an instrumental part. The conquest and temporary occupation of the Holy Land are presented to the audience as key events from its own antiquitas.

The old soldier next states flatly that the Gauls and, respectively, the French had everywhere subjugated other peoples and that this elevates Francia to 'Queen of the World' ('mundi regina') and to keeper of the imperium. ${ }^{33} \mathrm{He}$

31 'He also sings the praise of Moroveus [= Merovech] for his great bravery as well as of the proud Childeric who arose from that lineage as son. Childeric in merciless war vanquished the mighty sons of Rome, he defeated the wild Gillo [Aegidius] who ruled in those days [sc. over Rome] and he pushed back Odoacer with strong arms'.

32 'France, the courageous foster mother to great men, sent out great armies, with victorious arms subjugated the lands of the Orient, and ruled the Nabataean kingdoms taken in war after their tyrants had been defeated'.

33 Fol. LIX r: 'Quid verbis opus est? Totum diffusa per orbem / Francia sic populos contrivit Marte rebelles, / Ut mundi regina foret magnoque teneret / Imperio, quicquid gremio complectitur aequor' - 'What need is there for more words? Francia, spread all over the globe, has annihilated the rebellious peoples in war so much that it was queen of the 
concludes his speech by recalling how the Merovingian king Clovis I, after his victory over the Alemanni, was said to have converted to Christianity (fol. LIX $\mathrm{r}-\mathrm{v})$. Repeating the late medieval legend, the soldier recounts how Clovis was anointed with holy oil, received the Oriflamme from God and wore the French lilies on his coat of arms. Furnished with these divine attributes, the French had also defeated their Muslim adversaries in the Holy Land. ${ }^{34}$ Moreover, the Merovingians had met with success in fighting the Arianic Ostrogoths, i.e., other enemies of the Roman Church and of orthodoxy (fol. LIX v):

Arrius ambiguum cum sparsit virus in orbem

Oppressitque errore fidem, Gothus impius urbes

Francigenas invasit atrox, at fortibus armis

Cum duce supremam dedit inter praelia vitam. ${ }^{35}$

And on this note the old campaigner's oration ends. A second soldier now appears to extol Charlemagne and his deeds (fol. LX r):

Finierat senior. Iussus narrare secundus

Grandia commemorat magni certamina Carli,

Vicit ut Hunuldum et cogentem in bella cruentos

Vascones arma Lupum, ut magnum victricibus armis

Perfregit Desiderium, $[\ldots]$

$[\ldots]$

Saevaque Tartarei recolentes numina Ditis

Vicit ut atroces parvum [!] Saxones ad Hesam. ${ }^{36}$

Described here is how Charlemagne defeated Duke Hunold of Aquitaine, who then fled in the year 769 to the Basque Duke Lupos II, the ruler of Gascony,

world and with its great [sc. imperial] power ruled everything that the [world] ocean encircles in its lap'.

34 Fol. LIX v: 'Et merito: gens nulla fuit, quae fortius hostes / Vicerit et Machometiacas perfregerit aras' - 'Quite rightly: There has never been a people that has beaten the enemy more powerfully and destroyed the Mohammedan altars more effectively'.

35 'While Arius spread his poison in the teetering world and depressed the faith through his false teaching, the sinister, impious Goth attacked the Frankish towns but together with his leader found death in battle thanks to strong weapons'.

36 'The old man has finished. A second figure now is urged to tell of Charlemagne's famous battles, namely how he defeated Hunold and then Lupus who was forcing the bloody Gascons into war and passage at arms, and how he subdued the great Desiderius in victorious battles'. 
who, however, turned him over to Charlemagne in 770 and submitted to the king. It is recalled further that Charlemagne in 774 subdued the Langobard king Desiderius. In the following verses, finally, mention is made of the wars against the heathen Saxons (772-804). The second warrior also relates that the apostles had converted Europe's various peoples to Christianity (among them the holy Dionysius the Gauls), but that Spain had remained mired in superstition which was the reason for Charlemagne to march there and convert the Iberians by force of arms. ${ }^{37}$ And with that, the second soldiers's encomium also ends. The assembled nobles spend the remainder of the night in the tent praising the rest of the Frankish and French kings of the Middle Ages. ${ }^{38}$ This is how the epic concludes.

\section{Conclusion and Literary Historiographical Background}

In this epic, regarded as humanistic only because of the chronology, the portrayal of a glorious past does not concentrate on pagan antiquity but on late antiquity and medieval legend and, respectively, medieval history. However, the latter does not so much compete with Roman antiquity as it serves as its complement and culmination. Given this sort of perspective, the text is firmly anchored in the medieval tradition of epic narrative, and, indeed, Montmoret conceptually differs only slightly from the great French epic poets of the 12th and 13th centuries (Gilles of Paris, William the Breton, Nicolaus de Braia, among others). Still, it is highly unlikely that he knew of their works, much less used them as literary templates. Both temporally and culturally much closer is another epic by an Italian contemporary: the Carlias penned by the renowned

37 Fol. LX v: 'Horruit immensi leges Hispania Christi. / Ad quam magnanimus Francae moderator habenae / [...] / Armatos duxit proceres ritusque profanos, / Quos nequit sanctus sermone Iacobus iniquis / Dissuadere viris, valido mucrone revellit' - 'The Spanish lands recoiled before the laws of the mighty Christ. The magnanimous guide of the Frankish reins led his armed nobles into the land and eradicated with a mighty blade those heathen rituals from which the holy Jacob could not deter the misled people by his sermons'.

38 Fol. Lx v: 'Hos quoque, qui gestis famam meruere perennem, / Laudat quisque suo celebrandos ordine reges' - 'One after the other they also laud the praiseworthy kings who earned everlasting fame through their deeds'. 
Florentine Ugolino Verino (1438-1516). ${ }^{39}$ At least in the initial verses clear parallels can be detected between Montmoret and Verino: ${ }^{40}$

Montmoret I, 1-2 (fol. I r):

Praelia Francigenae canimus victricia gentis. ${ }^{41}$

Ugolino Verino, Carlias I, 1-2:

Praelia magnanimi canimus victricia Carli

Armaque Francorum nullis impervia terris. ${ }^{42}$

The Florentine poet had addressed the dedication copy of his epic to Charles VIII of France (1483-1498) and it is conceivable that the text circulated at the royal court (even if the dedication was unsuccessful and the codex was returned to the author in 1498 after the king's death).$^{43}$ Ugolino's work treats both the historic and the fabled and downright fanciful deeds of Charlemagne who is portrayed in the dedication as progenitor of the French royal house. Thus, a larger-than-life figure of France's medieval history is the focus of a humanistic epic that also relates in a certain way to France's contemporary history: As Charlemagne conquered the Langobards, so Charles viII subdues the Italian peninsula.

It is not only poetic traditions that are responsible for the fact that medieval antiquity plays such a prominent role in Montmoret's work and is featured at such length but so are two extraliterary rationales:

First, France and its kings emerge as the most important defenders of Christendom and the Roman church. Since pagan antiquity cannot contribute anything to this self-definition and self-portrayal, Montmoret has to let this people's relatable past begin in Christian late antiquity. He finds a rich trove of material in the Merovingian adoption of Catholicism, Charlemagne's missionary activity as well as the French kings' engagement in the Crusades of the High Middle Ages to stage a France guided by the 'most Christian king' (it is no coincidence that Charles viI was the first to officially adopt the title of Rex Christianissimus). That the religious aspect should figure so centrally in

39 Ugolino Verino, Carlias. Ein Epos des 15. Jahrhunderts, ed. N. Thurn, Humanistische Bibliothek. Texte und Abhandlungen. Reihe II. Texte 31 (Munich: 1995).

40 An exegesis of the first verse in Thurn N., Kommentar zur Carlias des Ugolino Verino, Humanistische Bibliothek. Texte und Abhandlungen. Reihe II. Texte 33 (Munich: 2002) 98.

41 'We sing of the victorious battles of the people descended from Francio'.

42 'We sing of the victorious battles of the noble-minded Charles and the weapons of the Franks, for whom no land is inaccessible'.

Thurn (ed.), Ugolino Verino, Carlias 12. 
Montmoret's epic is explained against the background of a prevailing Turkish menace that drove the most important political discourse in the Europe of the 15th and 16th centuries. France had to base its claim to religious leadership on a decidedly Christian-Catholic past to shore up its legitimacy and credibility in this debate, particularly with the Habsburg Empire.

The second reason for so clearly favouring the medieval past can be found in the military successes. The pagan antiquity mythos could only furnish losers: Francio and his companions had to flee from a Troy besieged by the Greeks. That would hardly yield any evidence of military competence. The Trojans were poor refugees who saved themselves by crossing the Mediterranean to the European coast in a boat. This contrasts with the different, more attractive foundation provided by medieval antiquitas: a long series of martial successes and territorial expansions. The Merovingian kings Charlemagne and Philipp II Augustus could serve as the most important protagonists in this success story. - The military aspect, too, must be analyzed against the early 16th century background: at that time, only someone who could look back on a glorious past crowned with victories in battle could venture to lay claim to military leadership of Europe, especially in the struggle against the Turks. Both the religious and the military aspects ultimately serve to present France as the political hegemon and leading nation that other, smaller states - for instance, in Italy or along the Rhine - had to submit to. To proclaim this message, the poet Montmoret harks back to layers of the past, some old, some more recent, which - going by modern epoch classification - reside not in Roman but in medieval antiquity.

\section{Bibliography}

Braun L., Ancilla Calliopeae. Ein Repertorium der neulateinischen Epik Frankreichs (1500-170o), Mittellateinische Studien und Texte 38 (Leiden - Boston: 2007).

Czapla R.G., Das Bibelepos in der Frühen Neuzeit. Zur deutschen Geschichte einer europäischen Gattung, Frühe Neuzeit 165 (Berlin - Boston: 2013).

Humbert of Montmoret, Bellorum Britannicorum a Carolo Francorum rege eo nomine septimo in Henricum Anglorum regem foelici eventu auspice puella franca gestorum prima pars continens Bellum Cravantinum, Bellum Brossimericum, Bellum Vernolianum et Bellum Aurelianum (Paris, Badius Ascensius: 1512).

IJsewijn J. (with D. Sacré), Companion to Neo-Latin Studies. Part II. Literary, Linguistic, Philological and Editorial Questions. Second, entirely rewritten edition, Supplementa Humanistica Lovaniensia 14 (Leuven: 1998). 
Kouskoff G., "Deux Epopées néo-latines à la gloire d'Hervé, le Nauchier breton”, in Chevallier R. (ed.), Colloque L'Épopée Gréco-Latine et ses Prolongements Européens. Caliope II (Paris: 1981) 199-216.

Provini S., "L'écriture épique de Germain de Brie et d'Humbert de Montmoret et l'humanisme italien" in Deramaix M. et al. (ed.), L'Italie et la France dans l'Europe latine du XIV au XVII siècle (Mont-Saint-Aignan: 2006) 79-93.

Provini S., L'Écriture épique au début de la Renaissance. Humbert de Montmoret, Germain de Brie, Pierre Choque, L'incendie de la Cordelière. Textes présentés et traduits (La Rochelle: 2004).

Thurn N., Kommentar zur Carlias des Ugolino Verino, Humanistische Bibliothek. Texte und Abhandlungen. Reihe II. Texte 33 (Munich: 2002).

Ugolino Verino, Carlias. Ein Epos des 15. Jahrhunderts, ed. N. Thurn, Humanistische Bibliothek. Texte und Abhandlungen. Reihe II. Texte 31 (Munich: 1995). 